\title{
PENDIDIKAN AGAMA ISLAM DALAM KELUARGA DOSEN TETAP AL-ISLAM KEMUHAMMADIYAHAN DI UNIVERSITAS MUHAMMADIYAH SUMATERA UTARA
}

\author{
Robie Fanreza \\ Dosen Fakultas Agama Islam Universitas Muhammadiyah Sumatera Utara \\ (Email: robiefanreza@yahoo.co.id)
}

\begin{abstract}
Abstrak
Betapa pentingnya menanamkan nilai-nilai pendidikan Islam didalam keluarga. Setiap orang tua tentu mendambakan anaknya menjadi anak yang saleh, yang memberi kesenangan dan kebanggaan kepada mereka. Kehidupan seorang anak tidak lepas dari keluarga (orang tua), karena sebagian besar waktu anak terletak dalam keluarga. Peran orang tua yang paling mendasar didalam mendidik agama kepada anak-anak mereka adalah sebagai pendidik yang pertama dan utama, karena dari orang tualah anak pertama kali menerima pendidikan, baik itu pendidikan umum maupun agama. Adapun peranan orang tua dapat dibedakan menjadi dua macam, yaitu : 1) Orang tua berfungsi sebagai pendidik keluarga, 2) orang tua berfungsi sebagai pemelihara serta pelindung keluarga.
\end{abstract}

Keywords: Pendidikan, Agama dan Keluarga

\section{A. Pendahuluan}

\subsection{Latar Belakang Masalah}

\section{Dengan pendidikan Islam,}

manusia dapat membentuk

kepribadian yang memungkinkan

kepada kedewasaan jasmani maupun

rohani sehingga terbina dengan baik

menuju kepada perkembangan dan

pertumbuhan yang wajar. Pendidikan

sebagai salah satu sarana yang efektif

untuk mengarahkan jiwa manusia ke

arah kepribadian yang baik, dengan

membentuk nilai-nilai yang sesuai

dengan hakikat kemanusiaan, yaitu

sebagai makhluk Tuhan yang tunduk

dan taat kepada-Nya bukan menjadi manusia yang selalu berbuat kejahatan dan meresahkan masyarakat.Jadi pada dasarnya pendidikan agama Islam berupaya untuk mengembangkan seluruh potensi peserta didik seoptimal mungkin, baik yang menyangkut aspek jasmaniah, mampu rohaniyah, akal, akhlak. Pendidikan agama Islam terus berupaya mengantarkan peserta didik kearah kedewasaaan pribadi secara paripurna, yaitu hamba yang beriman dan berilmu pengetahuan, semua itu diharapkan saling mempengaruhi antara satu dengn yang lain dalam 
perkembangannya mencapai tujuan pendidikan yang diinginkan, yaitu sebagai abd dan khalifah fil ardhi artinya pendidikan agama Islam sebagai agent of islamic culture akan mampu menjadikan dirinya sebagai contoh seluruh kehidupan manusia sehingga terciptanya kemaslahatan seluruh umat manusia di alam jagat raya ini. Pendidikan merupakan investasi yang paling utama bagi bangsa. Karena pembangunan hanya dapat dilaksanakan oleh manusia yang dipersiapkan untuk itu melalui pendidikan. Sistem pendidikan nasional yang dibangun selama ini ternyata belum mampu sepenuhnya menjawab kebutuhan dan tantangan global dewasa ini. Berbagai upaya dilakukan pemerintah untuk meningkatkan kualitas pendidikan belum menunjukkan hasil yang menggembirakan, bahkan masih banyak kegagalan antara lain disebabkan oleh masalah manajemen yang kurang tepat dan penempatan tenaga kerja yang tidak sesuai dengan keahlian. ${ }^{1}$

Dalam Nation Character
Building, bahwa pembinaan

${ }^{1}$ Oemar Hamalik, Manajemen Pelatihan Ketenagakerjaan Pendekatan Terpadu (Jakarta: Bumi Aksara, 2001) h. 1. keberagamaan merupakan kontribusi yang sangat besar terhadap perkembangan dan kemajuan suatu bangsa serta merupakan wahana dalam menerjemahkan pesan-pesan konstitusi serta sarana dalam membangun watak bangsa. Masyarakat yang cerdas akan senantiasa memberi nuansa kehidupan yang cerdas pula terhadap bangsanya. Memberi pembinaan terhadap masyarakat, terutama di bidang keagamaan merupakan salah satu tujuan nasional Negara Republik Indonesia yang di amanatkan dalam pembukaan Undang-Undang Dasar 1945. ${ }^{2}$ Untuk mewujudkan tujuan nasional tersebut, bangsa Indonesia senantiasa melaksanakan pembangunan yang bersifat fisik materil dan mental spiritual, antara lain melalui pembangunan di bidang agama yang mencakup suasana kehidupan beragama yang penuh keimanan dan ketakwaan terhadap Tuhan Yang Maha Esa, meningkatnya akhlak mulia, terwujudnya kerukunan hidup ummat beragama yang dinamis sebagai landasan persatuan dan kesatuan bangsa dalam meningkatkan peran

\footnotetext{
${ }^{2}$ Penjelasan atas Undang-Undang RI nomor 38 tahun 1999, h. 27
} 
serta masyarakat dalam pembangunan nasional.

\section{UMSU adalah Universitas} yang sangat menjunjung tinggi nilainilai Ke Islaman, hal ini terbukti dengan adanya mata kuliah yang bernuansa ke Islaman. Maka dari itu UMSU banyak mengangkat dosen tetap Al-Islam dan Kemuhammadiyahan dengan maksud untuk menanamkan nilainilai ke Islaman kepada para mahasiswa. Namun hal tersebut bukan jaminan bahwa dosen AlIslam dan Kemuhammadiyahan juga menerapkan nilai-nilai ke Islaman terhadap keluarganya, justru terkadang dosen tersebut hanya sibuk dengan aktifitas di kampus namun lupa terhadap keluarganya. Berdasarkan fenomena tersebut peneliti menangkat judul "Pendidikan Agama Islam Dalam Keluarga Dosen Tetap Al-Islam Kemuhammadiyahan Di Universitas Muhammadiyah Sumatera Utara".

\subsection{Rumusan Masalah}

Berdasarkan latar belakang dan fenomena di atas, maka dapat dirumuskan masalah sebagai berikut:
1. Bagaimana penerapan

Pendidikan Islam dalam Keluarga Dosen Tetap Al-Islam Kemuhammadiyahan?

2. Apa saja hambatan yang dialami oleh dosen tetap Al-Islam Kemuhammadiyahan dalam menerapkan pendidikan Islam dalam Keluarga ?

3. Bagaimana hasil dari penerapan Pendidikan Islam dalam keluarga dosen tetap Al-Islam Kemuhammadiyahan?

\subsection{Tujuan Penelitian}

Secara umum tujuan penelitian ini adalah untuk mengetahui penerapan pendidikan Islam dalam keluarga dosen tetap AlIslam Kemuhammadiyahan. Secara rinci dapat dikemukakan beberapa tujuan penelitian ini menjadi beberapa sub tujuan yaitu sebagai berikut:

1. Ingin mengetahui penerapan Pendidikan Islam yang dilakukan oleh dosen tetap AlIslam Kemuhammadiyahan dalam keluarga

2. Ingin mengetahui hambatanhambatan yang dialami oleh dosen tetap Al-Islam Kemuhammadiyahan dalam 
menerapkan pendidikan Islam di keluarga

3. Ingin mengetahui keberhasilan dosen tetap Al-Islam Kemuhammadiyahan dalam menerapkan Pendidikan Islam dalam Keluarga

\subsection{Manfaat}

Manfaat dari penelitian ini terbagi kedalam dua bagian yaitu:

1. Manfaat teoritis

1) Bahan kajian dalam menerapkan pendidikan Islam dalam keluarga para dosen AlIslam Kemuhammadiyahan.

2) Bahan informasi dalam proses penerapan pendidikan Islam keluarga

2. Manfaat praktis

Secara praktis hasil penelitian ini diharapkan memberikan manfaat bagi para peneliti yang memiliki objek penelitian yang sama. Khususnya bagi para peneliti yang memiliki latar belakang keilmuan di bidang Pendidikan Islam.

\section{B. STUDI PUSTAKA}

\subsection{Pengertian Pendidikan Islam}

Sebelum diuraikan mengenai pengertian pendidikan Islam, terlebih dahulu akan dijelaskan mengenai pengertian pendidikan secara umum agar pembahasannya lebih sistematis. Mengingat pengertian pendidikan Islam itutidak terlepas dari pengertian pendidikan pada umumnya. Dengan demikianakan kita ketahui arti dan batasan-batasan pendidikan Islam yang jelas. Rangkaian kata "pendidikan Islam" bisa dipahami dalam arti berbedabeda,antara lain: 1) pendidikan (menurut) Islam, 2) pendidikan (dalam) Islam,dan 3) pendidikan (agama) Islam. Istilah pertama, pendidikan (menurut) Islam, berdasarkan sudut pandang bahwa Islam adalah ajaran tentang nilainilai dan norma-norma kehidupan yang ideal, yang bersumber dari AlQur'an dan as-Sunnah. Dengan demikian, pembahasan mengenai pendidikan (menurut) Islamlebih bersifat filosofis. Istilah kedua, pendidikan (dalam) Islam, berdasar atas perspektif bahwa Islam adalah ajaran-ajaran, sistem budaya dan peradaban yang tumbuh dan berkembang sepanjang perjalanan sejarah umat Islam, sejak zaman Nabi Muhammad saw. sampai masa sekarang. Dengan demikian, pendidikan (dalam) Islam ini dapat 
dipahami sebagai proses dan praktik penyelenggaraan pendidikan di kalangan umat Islam, yang berlangsung secara

berkesinambungan dari generasi ke generasi sepanjang sejarah Islam. Dengan demikian, pendidikan (dalam) Islam lebih bersifat historis atau disebut sejarah pendidikan Islam. Sedangkan istilah ketiga, pendidikan (agama) Islam, muncul dari pandangan bahwa Islam adalah nama bagi agama yang menjadi panutan danpandangan hidup umat Islam. Agama Islam diyakini oleh pemeluknya sebagai ajaran yang berasal dari Allah, yang memberikan petunjuk ke jalan yang benarmenuju kebahagiaan di dunia dan keselamatan di akhirat. Pendidikan (agama) Islam dalam hal ini bisa dipahami sebagai proses dan upaya serta cara transformasi ajaran-ajaran Islam tersebut, agar menjadi rujukan dan pandangan hidup bagi umat Islam. Dengan demikian, pendidikan (agama) Islam lebih menekankan pada teori pendidikan Islam. ${ }^{3}$

${ }^{3}$ Lestari Ngatini, Pendidikan Islam Kontekstual (Djokjakarta: Pustaka Pelajar, 2010), h. 15-18
Pendidikan agama Islam adalah upaya sadar dan terencana dalam menyiapkan peserta didik untuk mengenal, memahami, menghayati, mengimani bertakwa berakhlak mulia, mengamalkan ajaran agama Islam dari sumber utamanya kitab suci al-Qur'an dan al-Hadits, melalui kegiatan bimbingan, pengajaran, latihan, serta penggunaan pengalaman. Pendidikan agama Islam bertujuan untuk meningkatkan keimanan, pemahaman, penghayatan, dan pengalaman peserta didik tentang agama Islam, sehingga menjadi manusia muslim yang beriman dan bertakwa kepada Allah Swt serta berakhlak mulia dalam kehidupan pribadi, bermasyarakat, berbangsa dan bernegara. ${ }^{4}$ Dari beberapa pengertian pendidikan agama Islam di atas penulis menyimpulkan bahwa pendidikan agama Islam adalah suatu usaha untuk menyiapkan peserta didik untuk meyakini, memahami dan mengamalkan ajaran agama Islam sehingga menjadi manusia yang beriman dan bertaqwa kepada

\footnotetext{
${ }^{4}$ Muhaimin, Paradigma Pendidikan Islam (Bandung: Remaja Rosdakarya, 2004), h. 78
} 
Allah Swt. dan berakhlak mulia dalam kehidupannya.

\subsection{Pengertian Keluarga Dalam}

\section{Islam}

Kata keluarga berasal dari bahasa Inggris yaitu family. Dalam kamus Besar Bahasa Indonesia. Keluarga adalah ibu dan bapak beserta anak-anaknya. Dalam memberikan pengertian keluarga, Hasan Langgulung mengungkapkan bahwa "Keluarga merupakan suatu unit sosial yang terdiri dari seorang suami dan seorang istri, atau dengan kata lain keluarga adalah perkumpulan yang halal antara seorang lelaki dan seorang perempuan yang bersifat terus menerus dimana yang satu merasa tentram dengan yang lain sesuai dengan yang ditentukan oleh agama dan masyarakat. Dan ketika suami istri itu dikaruniai seorang anak atau lebih, maka anak-anak itu menjadi unsure utama ketiga pada keluarga tersebut di samping dua unsur sebelumnya". 5

Muhaimin dan Abdul Mujib menulis bahwa dalam Islam keluarga

\footnotetext{
${ }^{5}$ Hasan Langgulung, Manusia dan Pendidikan (Jakarta: Pustaka Al Husna Baru, 2004), h. 24.
}

dikenal dengan istilah; usrah, nasl, ahli dan nasb. Keluarga dapat diperoleh melalui keturunan (anakcucu), perkawinan (suami-istri), persusuan dan pemerdekaan. ${ }^{6}$

\subsection{Pentingnya Pendidikan} Agama dalam Keluarga

Setiap orang tua tentu mendambakan anaknya menjadi anak yang saleh, yang memberi kesenangan dan kebanggaan kepada mereka. Kehidupan seorang anak tidak lepas dari keluarga (orang tua), karena sebagian besar waktu anak terletak dalam keluarga. Peran orang tua yang paling mendasar didalam mendidik agama kepada anak-anak mereka adalah sebagai pendidik yang pertama dan utama, karena dari orang tualah anak pertama kali menerima pendidikan,baik itu pendidikan umum maupun agama. Adapun peranan orang tua dapat dibedakan menjadi dua macam, yaitu: 1) Orang tua berfungsi sebagai pendidik keluarga, 2) orang tua berfungsi sebagai pemelihara serta pelindung keluarga.

1. Orang tua sebagai pendidik keluarga

\footnotetext{
${ }^{6}$ Muhaimin, Paradigma Pendidikan Islam,...h. 289.
} 
Dari orang tualah anak-anak menerima pendidikan, dan bentuk pertama dari pendidikan itu terdapat dalam keluarga. Oleh karena itu orang tua memegang peranan penting dan sangat berpengaruh atas pendidikan anak. Agar pendidikan anak dapat berhasil dengan baik ada beberapa hal yang perlu diperhatikan orang tua dalam mendidik antara lain:

a. Mendidik dengan ketauladanan (contoh).

Ketauladanan dalam pendidikan merupakan bagian dari sejumlah metode yang paling efektif dalam mempersiapkan dan membentuk anak secara moral, spiritual dan sosial. Seorang pendidik merupakan contoh ideal dalam pandangan anak yang tingkah laku dan sopan santunnya akan ditiru, bahkan semua keteladanan itu akan melekat pada diri dan perasaannya. Apabila kita perhatikan cara Luqman mendidik anaknya yang terdapat dalam surat Luqman ayat 15 bahwa nilai-nilai agama mulai dari penampilan pribadi luqman yang beriman, beramal saleh, bersyukur kepada Allah Swt dan bijaksana dalam segala hal, kemudian yang di didik dan di nasehatkan kepada anaknya adalah kebulatan iman kepada Allah Swt semata, akhlak dan sopan santun terhadap kedua orang tua, kepada manusia dan taat beribadah. Sehubungan dengan hal tersebut, hendaklah orang tua selaku memberikan contoh yang ideal kepada anak-anaknya, sering terlihat oleh anak melaksanakan sholat, bergaul dengan sopan santun. Berbicara dengan lemah lembut dan lainlainnya. Dan semua itu akan ditiru dan dijadikan contoh oleh anak.

b. Mendidik dengan adab pembiasaan dan latihan.

Setiap anak dalam keadaan suci, artinya ia dilahirkan di atas fitrah (kesucian) bertauhid dan beriman kepada Allah Swt. Oleh karena itu menjadi kewajiban orang tua untuk memulai dan menerapkan kebiasaan, pengajaran dan pendidikan serta menumbuhkan dan mengajak anak kedalam tauhid murni dan akhlak mulia. Hendaknya setiap orang tua menyadari bahwa dalam pembinaan pribadi anak sangat diperlukan pembiasaanpembiasaan dan latihan-latihan yang cocok dan sesuai dengan 
perkembangan jiwanya. Karena pembiasaan dan latihan itu akan membentuk sikap tertentu pada anak, yang lambat laun sikap itu akan terlihat jelas dan kuat, sehingga telah masuk menjadi bagian dari pribadinya. $^{7}$

Di sinilah bahwa pembiasaan dan latihan sebagai suatu cara atau metode mempunyai peranan yang sangat besar sekali dalam menanamkan pendidikan pada anak sebagai upaya membina akhlaknya. Peranan pembiasaan dan latihan ini bertujuan agar ketika anak tumbuh besar dan dewasa, ia akan terbiasa melaksanakan ajaran-ajaran agama dan tidak merasa berat melakukannya. Pembiasaan dan latihan jika dilakukan berulang-ulang maka akan menjadi kebiasaan, dan kebiasaan itulah yang nantinya membuat anak cenderung melakukan yang baik dan meninggalkan yang buruk dengan mudah.

c. Mendidik dengan nasehat

Di antara mendidik yang efektif di dalam usaha membentuk keimanan anak, mempersiapkan

\footnotetext{
${ }^{7}$ Abdullah Nashih Ulwan, Kaidahkaidah dasar (Pendidikan anak menurut Islam) (Bandung: Remaja Rosdakarya, 1992), h. 65.
}

moral, psikis dan sosial adalah mendidik dengan nasehat. Sebab nasehat ini dapat membukakan mata anak-anak tentang hakikat sesuatu dan mendorongnya menuju situasi luhur, menghiasinya dengan akhlak mulia, serta membekalinya dengan prinsip-prinsip Islam. Nasehat yang tulus berbekas dan berpengaruh jika memasuki jiwa yang bening, hati terbuka, akal yang bijak dan berpikir. Nasehat tersebut akan mendapat tanggapan secepatnya dan meniggalkan bekas yang dalam. Al Qur'an telah menegaskan pengertian ini dalam banyak ayatnya, dan berulang kali menyebutkan manfaat dari peringatan dengan kata-kata yang mengandung petunjuk dan nasehat yang tulus, di antaranya:

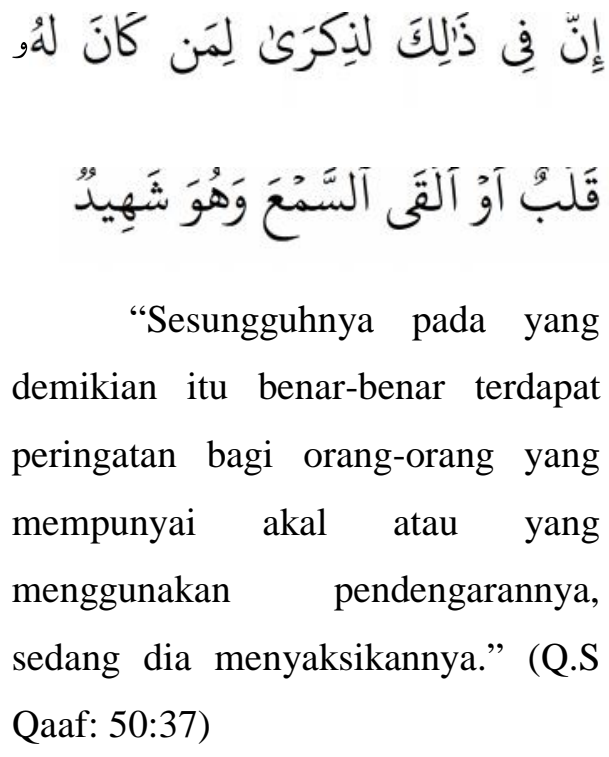
demikian itu benar-benar terdapat peringatan bagi orang-orang yang mempunyai akal atau yang menggunakan pendengarannya, sedang dia menyaksikannya." (Q.S Qaaf: 50:37) 

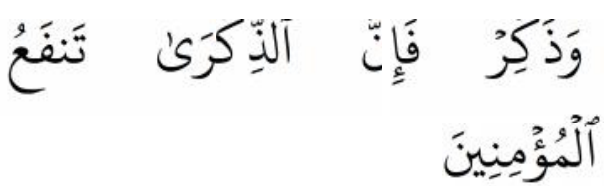

"Dan tetaplah memberi peringatan, karena sesungguhnya peringatan itu bermanfa'at bagi orang-orang yang beriman". (Q.S Dzariyat: 51:55)

Nasehat sangat berperan dalam menjelaskan kepada anak tentang segala hakekat serta menghiasinya dengan akhlak mulia. Nasehat orang tua jauh lebih baik dari pada orang lain, karena orang tualah yang selalu memberikan kasih sayang serta contoh perilaku yang baik kepada anaknya. Disamping memberikan bimbingan serta dukungan ketika anak mendapat kesulitan atau masalah, begitupun sebaliknya ketika anak mendapatkan prestasi.

\subsection{Mendidik Dengan Pengawasan}

Pendidikan yang disertai pengawasan yaitu mendampingi anak dalam upaya membentuk akidah dan moral, mengasihinya dan mempersiapkan secara psikis dan sosial, memantau secara terus menerus tentang keadaannya baik dalam pendidikan jasmani maupun dalam hal belajarnya. Mendidik yang disertai pengawasan bertujuan untuk melihat langsung tentang bagaimana keadaan tingkah laku anak sehariharinya baik di lingkungan keluarga maupun sekolah. Di lingkungan keluarga hendaknya anak tidak selalu dimarahi apabila ia berbuat salah, tetapi ditegur dan dinasehati dengan baik. Sedangkan di lingkungan sekolah, pertama-tama anak hendaknya diantar apabila ia ingin pergi ke sekolah. Supaya ia nanti terbiasa berangkat kesekolah dengan sendiri. Begitu pula setelah anak tiba di rumah ketika pulang dari sekolah hendaknya ditanyakan kembali pelajaran yang ia dapat dari gurunya.

\section{METODE PENELITIAN}

\subsection{Alasan Menggunakan}

\section{Metode Kualitatif}

Penelitian ini adalah

Kualitatif yaitu jenis penelitian yang menghasilkan penemuan-penemuan yang dijelaskan dalam bentuk paparan serta uraian. Penelitian ini mengunakan pendekatan yang diarahkan pada latar dan individu secara holistik (utuh). Sehingga dalam hal ini tidak boleh mengisolasikan individu atau organisasi ke dalam variabel atau 
hipotesis, tetapi memandangnya sebagai bagian dari suatu keutuhan. Menurut Bogdan dan Taylor sebagaimana dikutip Moleong metodologi kualitatif adalah sebagai prosedur penelitian yang menghasilkan data deskriptif berupa kata-kata tertulis atau lisan dari orang-orang dan perilakuyang daimati. $^{8}$

Alasan peneliti menggunakan metode kualitatif adalah karena penelitian ini cenderung kepada pendeskripsian kualitas data dan bukan kepada kuantitas atau hasil dari penelitian tetapi lebih cenderug kepada proses penelitian.

\subsection{Tempat Penelitian}

Penelitian ini dilakukan di Universitas Muhammadiyah Sumatera Utara Jl. Muktar Basri No 3 Medan.

\subsection{Sumber Data Penelitian}

Data dalam penelitian ini ada dua macam, yaitu : data primer dan data sekunder. Data primer adalah data utama dalam penelitian, sedangkan data sekunder adalah data pendukung. Data primer diperoleh

${ }^{8}$ Lexy J. Moleong, Metodologi Penelitian Kualitatif, Cet I (Bandung: Remaja Rosdakarya, 2000), h. 3 dari para informan yang diambil secara purposive (bertujuan). Informan penelitian yang dimaksud adalah para dosen $\mathrm{Al}$ Islam Kemuhammadiyahan Universitas Muhammadiyah Sumatera Utara. Sementara data sekunder adalah data tambahan yang digunakan sebagai pendukung data primer. Data sekunder biasanya berwujud data dokumentasi atau data yang telah tersedia. Data sekunder diperoleh dari dokumentasi pengamalan agama, kemudian bahan-bahan bacaan yang relevan dengan objek penelitian.

\subsection{Tehnik Pengumpulan Data}

Keberhasilan dalam penelitaian ini adalah bagaimana supaya dapat menghimpun data yang dibuktikan. Pengumpulan data dalam penelitian kualitatif menggunakan teknik observasi, wawancara mendalam (in depath interview) dan pengkajian dokumen. Pengumpulan data kualitatif menurut Lincoln \& Guba menggunakan wawancara observasi dan dokumen ( catatan atau arsip). Pada penelitian ini data diperoleh dengan menggunakn teknik observasi bereperan serta (partipant observatian) terhadap 
situasi sosial dalam aktivitas manjemen pemebelajaran untuk dapat meningkatkan mutu pendidikan agama Islam. observasi partisipan yang digunakan ialah peran subjek penelitian

Penelitian harus terjun ke lapangan sebagai instrumen utama dalam penelitian ini, oleh karena itu ada beberapa teknik pengumpulan data agar dapat dilakukan oleh peneliti yakni:

\section{a. Observasi (pengamatan)}

Metode observasi yaitu metode pengumpulan data dengan pengamatan dan pencatatan secara sistematis terhadap fakta-fakta yang diselidiki. Menurut Suharsimi Arikunto"metode observasi adalah pengamatan meliputi kegiatan perumusan perhatian terhadap suatu obyek menggunakan seluruh alat indera. ${ }^{9}$ Sedangkan menurut Margono“Observasi diartikan sebagai pengamatan dan pencatatan secara stematik terhadap gejala yang tampak pada objek penelitian. ${ }^{10}$

\footnotetext{
${ }^{9}$ Suharsimi Arikunto, Prosedur Penelitian Suatu Pendekatan Praktis( Jakarta: Rineka Cipta, 2006), h.128.

${ }^{10}$ Margono, Metodologi Penelitian Pendidikan (Jakarta: Rineka Cipta, 1997), h. 158 .
}

Pengamatan dan pencatatan yang dilakukan terhadap objek ditempat terjadi atau berlangsungnya peristiwa, sehingga observasi berada bersama obyek yang diselidiki, disebut observasi langsung. Sedang observasi tidak langsung adalah pengamatan yang dilakukan tidak pada saat berlangsungnya suatu peristiwa yang akan diselidiki, misalnya peristiwa tersebut diamati melalui film, rangkaian slide, atau rangkaian photo. ${ }^{11}$

Peneliti melakukan dua tahap observasi yang sifatnya umum dan yang khusus. Yang bersifat umum adalah pengamatan dilakukan terhadap berbagai unsur seperti metode pengajaran yang dilakukan oleh dosen-dosen Al-Islam dalam menyampaikan Agama kepada keluarganya.

Sedangkan yang bersifat
khusus adalah peneliti melihat
langsung dan mencatat situasi yang
berkaitan dengan pengamalan nilai-
nilai Islam yang terdapat di keluarga
dosen AL Islam.

\subsection{Tehnis Analisis Data}

Analisa data ialah proses menyusun atau mengolah data agar

\footnotetext{
${ }^{11}$ Margono, Metodologi... h. 159.
} 
dapat ditafsirkan lebih baik.

Selanjutnya Moleong berpendapat bahwa analisa data dapat juga dimaksudkan untuk menemukan unsur-unsur atau bagian-bagian yang berisikan kategori yang lebih kecil dari data penelitian. ${ }^{12}$ Data yang baru didapat dari catatan lapangan yang diperoleh melalui observasi, wawancara dan studi dokumen pada masalah tentang pengamalan nilainilai Ke Islaman dianalisis dengan cara menyusun, menghubungkan dan mereduksi data, penyajian data, penarikan kesimpulan data selama dan sesudah pengumpulan data.

Untuk itu data yang didapat kemudian dianalisis dengan menggunakan analisis data kualitatif yang terdiri dari:

(a) Reduksi data

Reduksi data adalah proses pemilihan, perumusan, perhatian pada penyederhanaan atau menyangkut data dalam bentuk uraian (laporan) yang terperinci dan sistematis, menonjolkan pada pokok-pokok yang penting agar lebih mudah dikendalikan.

Reduksi data merupakan satu bentuk analisis yang menajamkan, 87.

\footnotetext{
${ }^{12}$ Lexy J.Moleong, Metodologi ...,h.
}

menggolongkan, membuang yangtidak perlu, yang akan memberikan gambaran yang lebih terarah tentang hasil pengamatan, dan juga mempermudah peneliti untuk mencari kembali data itu apabila diperlukan. Display data merupakan upaya penyajian data untuk melihat gambaran keseluruhan data atau bagian-bagian tertentu dari penelitian. Data yang dikumpulkan tidak semuanya valid dan reliable, karenanya perlu dilakukan reduksi agar data yang akan dianalisis benar-benar memiliki validitas dan reliabilitas yang tinggi.

Jadi data yang diperoleh melalui observasi, wawancara dan studi dokumen dikumpulkan diseleksi kemudian dikelompokkan kemudian ditarik kesimpulan dari penelitian tersebut tanpa menghilangkan nilai data itu sendiri. (b) Penyajian data

Sajian data adalah rangkaian organisasi informasi yang memungkinkan kesimpulan riset dapat dilakukan.

Sajian data diperlukan peneliti untuk lebih mudah memahami berbagai hal yang terjadi 
dan memungkinkan mengerjakan sesuatu pada analisis ataupun tindakan lain berdasarkan pemahaman. Sajian data dapat berupa berbagai jenis matrik,gambar skema, jaringan kerja yang berkaitan dengan kegiatan dan jugatable.

Penyajian data ini juga berkaitan dengan sekumpulan informasi yang tersusun yang memberi kemungkinan adanya penarikan kesimpulan dan pengambilan tindakan selanjutnya.

(c) Kesimpulan,

Sejak awal kegiatan pengumpulan data seorang peneliti sudah harus memahami arti berbagai hal yang dimulai dengan mulai melakukan pencatatan-pencatan peraturan-peraturan, pola-pola, pernyataan-pernyataan, konfigurasikonfigurasi yang mungkin, arahan sebab akibat dan berbagai proposisi.

Kesimpulan atau verifikasi adalah upaya untuk mencari makna terhadap data yang dikumpulkan dengan mencari pola, tema, hubungan, persamaan, hal-hal lain yang sering timbul dan sebagainya. Pengambilan kesimpulan atau verifikasi dilakukan secara bertahap.
Pertama-tama dirumuskan kesimpulan sementara, akan tetapi dengan bertambahnya data perlu dilakukan dengan cara mempelajari kembali data-data yang terkumpul, baik yang telah direduksi maupun yang telah disajikan.

Demikian juga verifikasi ini dilakukan dengan cara meminta pertimbangan dari pihak-pihak yang berkompeten. Teknik pengambilan kesimpulan dan penelitian ini adalah teknik analisis induksi berdasarkan bagian-bagian yang telah dikumpulkan, kemudian dikelompok yang saling berhubungan. Reduksi data, penyajian data, dan penarikan kesimpulan atau verifikasi sebagai sesuatu yang jalin menjalin pada saat sebelum, selama, dan sesudah pengumpulan data dalam bentuk yang sejajar. Tiga jenis kegiatan analisis (Reduksi data, sajian data, verifikasi atau penarikan kesimpulan) dan kegiatan pengumpulan data merupakan siklus dan interaktif. ${ }^{13}$

Pada tahap awal pengumpulan data, fokus penelitian masih melebar dan belum tampak jelas, sedangkan observasi masih bersifat umum dan

\footnotetext{
${ }^{13}$ Moleong, Metodologi....h. 67.
} 
luas. Setelah fokus semakin jelas maka peneliti menggunakan observasi yang lebih berstruktur untuk mendapatkan data yang lebih spesifik.

Kasus dalam hal ini menjadi kekuatan atau satuan analisis dalam pengumpulan data baik dalam suatu kasus maupun berbagai kasus, bahkan sub kasus. Dalam pengumpulan data kasus ini menjadi fokus sekaligus satuan analisis (mencakup satuan sosial, fisik dan waktu atau rangkaian waktu). Adapun kasus-kasus dalam penelitian ini dibedakan atas kasus utama, kasus negatif dan kasus ekstrim.

Keberadaan kasus utama adalah kasus-kasus yang menjadi perhatian utama, terdapat pada keempat situs dan mencakup keempat parameter di atas. Kriteria utama dalam penentuan kasus adalah informasi penting yang diperlukan dan sesuai dengan fokus serta dapat digunakan sebagai satuan analisis atau kasus terpilih. Informasi-informasi yang diperoleh dari kasus utama ini merupakan data induk, data yang harus diperiksa lagi keabsahannya melalui kasus negatif dan kaidah-kaidah keabsahan lainnya.

\subsection{Rencana Pengujian}

\section{Keabsahan Data}

Dalam penelitian kualitatif faktor keabsahan data juga sangat diperhatikan karena suatu hasil penelitian tidak ada artinya jika tidak mendapat kepercayaan. Untuk memperoleh kepercayaan dan pengakuan terhadap hasil penelitian ini terletak pada keabsahan data penelitian yang sudah dikumpulkan.

Untuk mencapai kebenaran digunakan teknik kredibilitas, transferbilitas, dependibilitas dan konfirmibilitas yang terkait dengan pengumpulan data dan analisis data.

Dalam penelitian ini data harus diterima untuk mendukung kesimpulan penelitian. Oleh karena itu perlu digunakan standar keshahihan data yang terdiri dari 1). Kepercayaan (credibility), 2). Dapat keteralihan (transferability), 3). Keterandalan (dependability),4). Komfirmibilitas (comfirmability) $)^{14}$ yang dijelaskan:

a. Kepercayaan ( credibility)

\footnotetext{
${ }^{14}$ Moleong,Metodologi...h. 90
} 


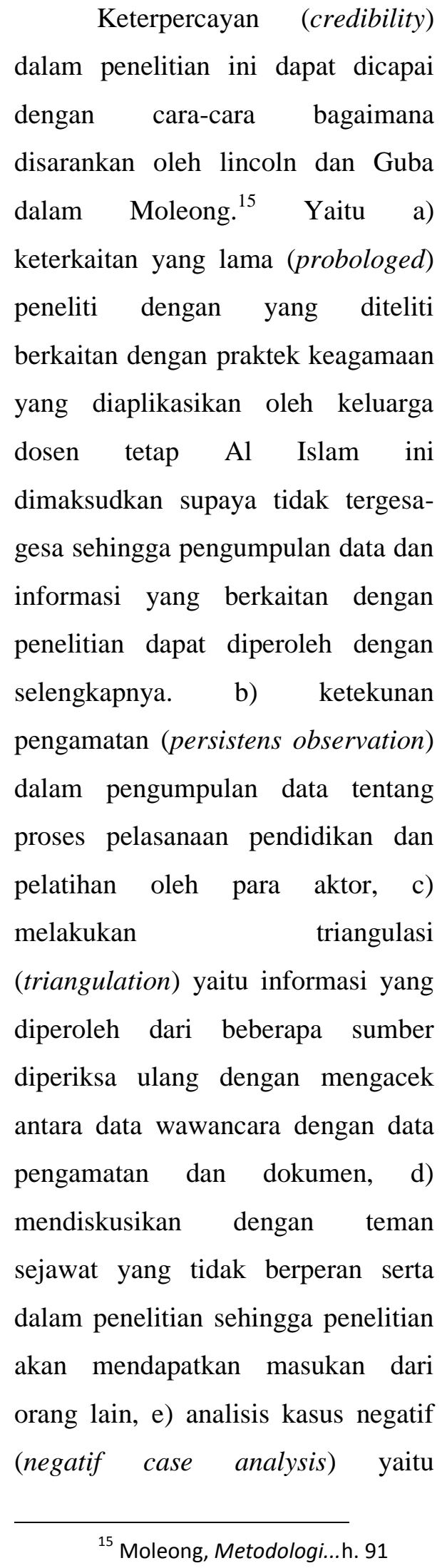

Keterpercayan (credibility)

menganalisa dan mencari kasus atau keadaan yang menyanggah temuan penelitian sehingga tidak ada lagi bukti yang menolak temuan penelitian, f) pengujian ketepatan referensi data temuan dan intepretasi, laporan penelitian dalam hal ini dikonsultasikan dengan pemibimbing.

b. Keteralihan (transferability)

Yaitu agar pembaca mendapatkan gambaran yang jelas mengenai latar penelitian dengan maksud agar penelitian ini dapat diaplikasikan atau diberlakukan kepada konteks atau situasi yang sejenis. Criteria ini disebut juga dengan validitas eksternal, yaitu sejauh mana hasil penelitiannya dapat diterapkan atau digunakan di tempat dan situasi yang berbeda. Dengan kata lain keteralihan ini disebut juga dengan generalisasi.

c. Keterandalan (dependability)

Data penelitian harus dapat dihandalkan. Dalam hal ini dapat diandalkan (dependability) berarti peneliti mengusahakan konsistensi keseluruhan proses penelitian ini agar memenuhi persyaratan yang berlaku. Peneliti tidak boleh ceroboh 
atau membuat kesalahan dalam mengkonsep studinya, mengumpulkan data, menjelaskan dan melaporkan hasil penelitian.

\section{d. Dapat dikonfirmasilkan (confirmability) \\ Data dikonfirmasikan} (confirmability) yaitu hasil penelitian harus dapat diakui oleh orang banyak (objektivitas). Berkaitan dengan kualitas hasil penelitian, kualitas data dan interpretasikan harus didukung oleh bahan yang koheren (sesuai), dengan kata lain, melakukan konfirmasi merupakan suatu proses mengacu pada hasil penelitian. Apabila konfirmasikan ini menunjukan data cukup koheren, maka temuan penelitian di pandang memenuhi syarat, tetapi bila tidak cukup koheren maka temuan dianggap gugur dan penelitian kembali ke lapangan mengumpulkan data.

\section{Kesimpulan Dan Saran}

\subsection{Kesimpulan}

Kesalehan anak dalam keluarga dapat dilihat dari orang tuanya menanamkan nilai pendidikan agama. Sebaiknya perlakuanperlakuan yang dicontohkan kepada anak seharusnya bernilai agama.
Anak akan jauh lebih mudah melihat bahkan mencontoh orang tuanya dalam bertindak atau bertingkah laku.

Kesalehan orang tua hal yang paling fundamental bagi anaknya. Jika kesalehan keduanya, tentunya akan akan menjadi shaleh juga. Anak-anak tumbuh sesuai yang dibiasakan orang tuanya. Ibu lebih didahulukan terlebih dahulu dari sang ayah sebab beban terbesar dalam pendidikan anak berada di pundak ibu, mengingat kebersamaannya yang lebih lama dengan anak-anak, berbeda dengan ayah yang lebih sering berada diluar rumah dalam mencari nafkah.

Maka perlu kerjasama antara ibu dan ayah dalam mendidik dan menanamkan nilai-nilai agama. Dengan kerjasasama yang baik insyallah akan melahirkan anak-anak yang shaleh.

\subsection{Saran}

Menanamkan nilai-nilai keshalehan anak harus dikerjakan secara bersamaan ibu dan ayah. Dan Para orang tua hendaknya memperhatikan perkara penting yang memiliki pengaruh besar pada kepribadian anak yaitu interaksi antara orang tua. Interaksi antar kedua orang tua adalah pendidikan harian yang disaksikan langsung oleh anak-anak di depan mata mereka. 
Ada analogi yang dapat dijadikan pelajaran penting bagi orang tua jika pohon yang berbuah kemudian buah itu jatuh tidak akan jauh dari pohonnya. Anak biasanya karekternya tidak jauh berbeda dari kedua orang tuanya. Maka berikan teladan yang baik kepada anak.

\section{Daftar Pustaka}

Abdullah Nashih Ulwan, Kaidahkaidah dasar (Pendidikan anak menurut Islam) (Bandung: Remaja Rosdakarya, 1992).

Hasan Langgulung, Manusia dan Pendidikan (Jakarta: Pustaka Al Husna Baru, 2004).

Lestari Ngatini, Pendidikan Islam Kontekstual (Djokjakarta: Pustaka Pelajar, 2010).

Lexy J. Moleong, Metodologi Penelitian Kualitatif, Cet I (Bandung: Remaja Rosdakarya, 2000).

Margono, Metodologi Penelitian Pendidikan (Jakarta: Rineka Cipta, 1997).

Muhaimin, Paradigma Pendidikan Islam (Bandung: Remaja Rosdakarya, 2004).

Oemar Hamalik, Manajemen Pelatihan Ketenagakerjaan Pendekatan Terpadu (Jakarta: Bumi Aksara, 2001).
Penjelasan atas Undang-Undang RI nomor 38 tahun 1999.

Suharsimi Arikunto, Prosedur Penelitian Suatu Pendekatan Praktis( Jakarta: Rineka Cipta, 2006). 